\title{
OPTIMASI FREKUENSI DAN TEMPERATUR PEMANASAN PADA PELEBURAN TIMAH DALAM TUNGKU INDUKSI DENGAN KAPASITAS 0,45 KG
}

\author{
Dja'far Sodiq', Rafi Ardiansyah ${ }^{2}$ \\ Jurusan Teknik Konversi Energi, Politeknik Negeri Bandung \\ E-mail: $\underline{\text { Rafiardiansyah43@yahoo.co.id }}$
}

\begin{abstract}
ABSTRAK
Peleburan material, baik logam maupun non-logam, menggunakan tungku induksi merupakan salah satu pilihan teknologi alternatif, selain teknologi konvensional pembakaran secara langsung. Sumber panas pada tungku induksi diperoleh dari aliran arus listrik AC (alternating current) yang dilewatkan melalui kumparan yang melingkupi inti besi. Hal ini menimbulkan induksi elektromagnet yang menghasilkan arus induksi (eddy current), yang selanjutnya memberikan panas pada inti besi yang berperan sebagai cawan tempat peleburan material. Material utama cawan, yaitu ST37, juga memberi kontribusi terhadap rugi-rugi histerisis. Untuk menunjang proses peleburan, alat tungku induksi dilengkapi dengan komponen penunjang, yaitu timah, kawat email, rangkaian pengendali frekuensi, rangkaian tenaga (power), dan lainnya. Parameter yang divariasikan adalah frekuensi $200 \mathrm{~Hz}, 250 \mathrm{~Hz}$, $300 \mathrm{~Hz}$, dan $325 \mathrm{~Hz}$. Dan parameter tetap adalah tegangan 50 Volt dan waktu pemanasan selama 20 menit. Sementara parameter yang digunakan untuk mengukur performansi tungku induksi peleburan ini adalah temperatur pemanasan akibat penyaluran listrik AC dengan arus dan frekuensi yang bervariasi. Performansi terbaik diperoleh pada frekuensi tertinggi, yaitu $325 \mathrm{~Hz}$, yang menghasilkan temperatur pemanasan sebesar $191,9^{\circ} \mathrm{C}$ untuk cawan kosong dan $161,3^{\circ} \mathrm{C}$ untuk cawan terisi timah yang dipanasi selama 20 menit. Kecendurangan hasil pengujian menunjukkan bahwa makin tinggi frekuensi, maka waktu pemanasan semakin efektif.
\end{abstract}

Kata Kunci: Tungku induksi, elektromagnet, arus Eddy, hysterisis

\section{ABSTRACT}

Metal or non-metal material melting using induction furnace is one of alternative technology, instead of conventional direct combustion technology. Heat source for induction furnace gained from AC current passed through coil that surrounding iron core. This current generated electromagnetic induction that produced eddy current, which then generate heat in iron core as material melting cup. The main material of cup is ST37, that also contribute in hysteresis losses. And the supporting material is tin, enamel wire, a set of frequency control circuit, a set of power circuit, and other supporting components. Varied parameter was frequency of $200 \mathrm{~Hz}, 250 \mathrm{~Hz}, 300 \mathrm{~Hz}$, and $325 \mathrm{~Hz}$. And fix parameter was 50 Volt voltage and 20 minutes heating time. The parameter used to measure performance of induction furnace was heating temperature. The best performance obtained at $325 \mathrm{~Hz}$ frequency that generated $191,9^{\circ} \mathrm{C}$ in empty cup and $161,3^{\circ} \mathrm{C}$ in tin filled cup that heated for 20 minutes. The trend of testing result showed that the higher frequency, the more effective heating time.

Keywords: Induction furnace, electromagnet, Eddy current, hysterisis 


\section{PENDAHULUAN}

Kebutuhan energi khususnya energi panas, semakin hari semakin meningkat. Salah satu aplikasi energi panas dalam kehidupan seharihari yaitu pada industri peleburan logam maupun non logam. Dengan perkembangan modernisasi yang banyak memanfaatkan hasil olahan logam dan non-logam, maka kebutuhan akan penggunaan material logam maupun non logam semakin meningkat. Oleh karena itu, industri peleburan berupaya meningkatkan produksi sehingga kebutuhan pasar terpenuhi.

Teknologi yang banyak digunakan untuk meleburkan logam maupun non logam adalah dengan cara burner (pembakaran). Akan tetapi, teknologi burner memiliki kelemahan dalam hal konsumsi bahan bakar yang tidak sedikit. Bahan bakar yang biasa digunakan adalah LNG dan LPG (energi fosil). Selain itu, dalam proses peleburan material, faktor keselamatan juga menjadi perhatian khusus, karena berhubungan dengan temperatur yang sangat tinggi, sehingga sangat berbahaya apabila panas yang dihasilkan terkena manusia (Abrianto, 2009). Apalagi dengan menggunakan teknologi burner, panas yang dihasilkan berasal dari pembakaran (api). Untuk itu, diperlukan teknologi alternatif yang lebih aman dalam proses peleburan, yaitu dengan menggunakan tungku induksi (induction furnace).

\section{Tungku Induksi}

Tungku induksi memiliki beberapa kelebihan. Selain lebih aman, juga tidak menggunakan bahan bakar untuk menghasilkan panas, sehingga dapat mengurangi penggunaan energi fosil. Tungku induksi menggunakan listrik sebagai daya input untuk menghasilkan panas. Panas yang terjadi diakibatkan oleh induksi elektromagnet pada cawan sebagai inti besi. Selain itu, kelebihan tungku induksi yaitu menghasilkan produk cair yang bersih tanpa menghasilkan kerak. Untuk itu, tungku induksi cocok digunakan dalam proses peleburan.

Tungku induksi adalah tungku yang menggunakan energi listrik sebagai sumber energi panasnya, dimana arus listrik bolakbalik (alternating current) yang melewati kumparan akan menghasilkan medan magnetik pada logam. (Abrianto, 2009). Tungku induksi adalah tungku dengan proses perpindahan panas secara tidak langsung, dimana material yang akan dileburkan atau dipanaskan dihindarkan dari kontak langsung terhadap sumber panas. Objek yang akan dileburkan ditempatkan dalam wadah yang disebut cawan. Cawan tersebut harus terbuat dari bahan bersifat konduktif, supaya terjadi induksi elektromagnet yang menimbulkan panas. Material cawan juga harus memiliki titik lebur lebih tinggi dari objek peleburan, supaya tidak ikut melebur. Maka, pemilihan material cawan harus memiliki titik lebur, hambatan jenis, serta dimensi yang sesuai.

\section{Prinsip Kerja Tungku Induksi}

Tungku induksi memanfaatkan pemanasan dari dua jenis rugi-rugi yang biasa dihindari pada penggunaan generator maupun transformator. Dua jenis sumber panas tersebut adalah arus Eddy dan hysteresis.

\section{1) Arus Eddy}

Arus eddy merupakan faktor pemanasan yang paling dominan. Arus eddy adalah arus yang timbul dari adanya pemotongan medan magnet oleh penghantar/konduktor yang digerakkan di sekitar medan magnet. Arus ini juga timbul apabila ada sebuah konduktor yang diam, sementara ada medan magnet yang bergerak secara bolak balik terhadap konduktor tersebut. Gambar 1 menjelaskan terjadinya arus eddy. Medan magnet yang ditimbulkan akan menyebabkan medan induksi. Medan induksi ini akan menghasilkan medan pusaran. Jika bahan inti yang dijadikan jalur medan magnet ini bersifat kondukif, maka medan pusar ini akan menghasilkan arus pusar pada inti.

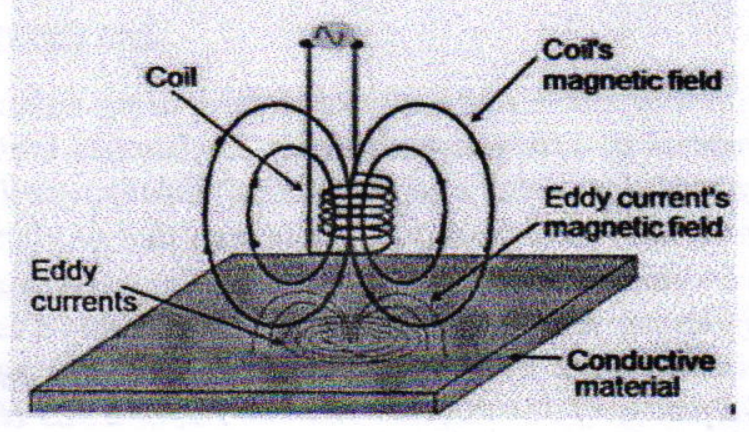

Gambar 1. Arus Eddy Pada Permukaan Bahan

\section{2) Hysterisis}

Hysterisis adalah suatu energi untuk mengubah intensitas fluks dari induksi residu menjadi nol. Energi ini digunakan untuk mengatasi suatu hambatan dari pergeseran intensitas fluks yang terjadi. Penggunaan energi ini akan menyebabkan panas yang juga 
dimanfaatkan untuk memanaskan benda kerja. Jadi, ketika sebuah kumparan dihubungkan dengan sebuah sumber arus AC, maka akan menghasilkan arus I, dengan nilai dari nol sampai maksimal. Seiring dengan pertambahan arus I maka nilai $\mathrm{H}$ dan $\mathrm{B}$ juga meningkat (berbanding lurus). Peningkatan nilai $\mathrm{H}$ dan $\mathrm{B}$ akan terlihat seperti pada Gambar 2.

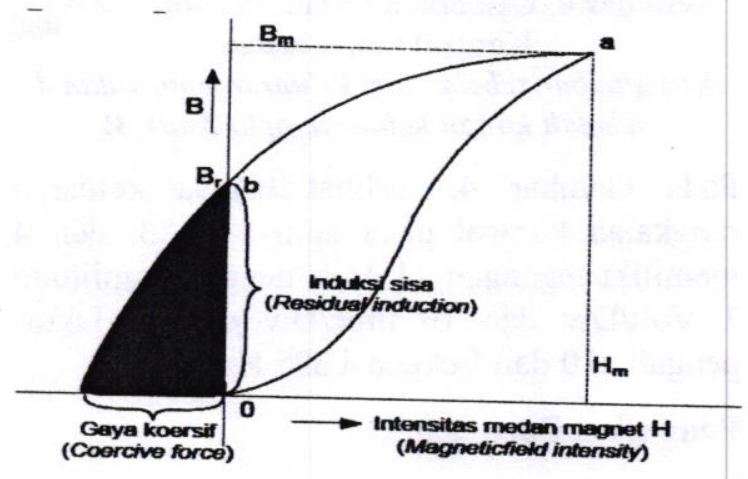

Gambar 2. Kurva Karakteristik Hysterisis (Sumber: Reitz dkk, 1993)

Ketika arus naik, maka medan magnet $\mathrm{B}$ akan naik diikuti kenaikan $\mathrm{H}$ sesuai kurva 0 -a, dan ketika arus turun menuju 0 (nol), maka akan diikuti dengan penurunan $\mathrm{B}$, akan tetapi penurunannya mengikuti kurva a-b di atas kurva 0-a. Sama juga berarti jika menurunkan intensitas medan magnet $(\mathrm{H})$, maka intensitas fluks akan berusaha untuk mempertahankan nilainya. Hal itulah yang disebut hysterisis. Akibatnya saat $\mathrm{H}$ diturunkan hingga mencapai harga nol, masih ada nilai intensitas medan (B) yang tersisa yang disebut remanence.

\section{METODOLOGI}

Pada penelitian pembuatan tungku induksi ini, dilakukan beberapa tahap. Tahap pertama, yaitu studi literatur referensi mengenai tungku induksi. Selanjutnya, melakukan perancangan alat untuk memperoleh data pengujian. Pada tahap perancangan tungku induksi ini, beberapa hal harus dilakukan, yaitu: menentukan material yang akan dilebur, menentukan material untuk cawan, dan pembuatan rangkaian frekuensi inverter dengan tipe half bridge (dengan 4 buah mosfet). Adapun gambaran umum mengenai alat yang dibuat, dapat dilihat pada diagram blok (Gambar 3).

Sumber panas yang diakibatkan oleh rugi eddy dan rugi hysterisis harus diatur agar sesuai dengan yang diinginkan. Untuk itu, terdapat beberapa hal yang harus diperhitungkan, yaitu arus Eddy dan hysterisis.

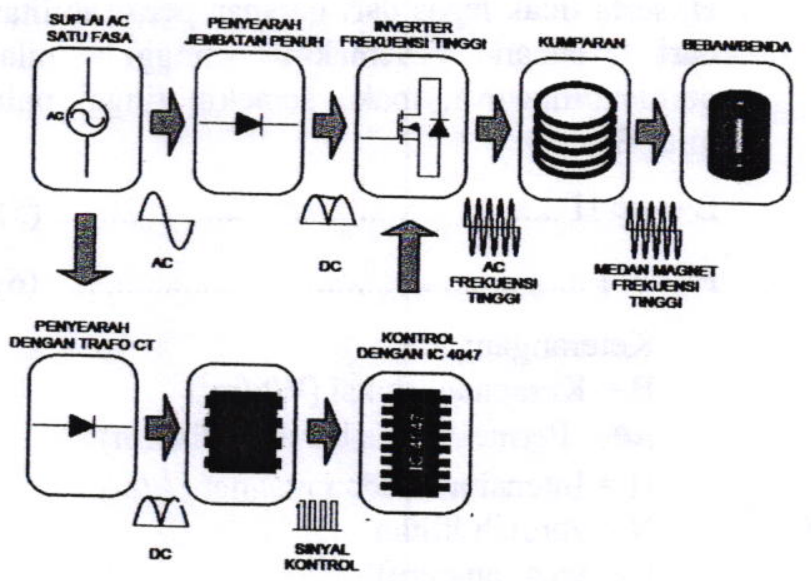

Gambar 3. Diagram Blok Perancangan

1) Rugi eddy

Panas yang dihasilkan pada material sangat bergantung kepada besarnya arus eddy yang diinduksikan oleh lilitan penginduksi. Maka, arus yang melewati konduktor tentunya memiliki sifat resistif pada konduktornya, sehingga muncul persamaan (1).

$P=I^{2} R$

Sejalan dengan lamanya (waktu), maka daya tersebut akan menjadi energi panas dengan persamaan (2).

$\mathrm{P}=\mathrm{I}^{2} \mathrm{R} \mathrm{t}$

$$
\begin{aligned}
& \text { Keterangan: } \\
& \mathrm{P}=\text { Energi Panas (Joule) } \\
& \mathrm{I}=\text { Arus (ampere) } \\
& \mathrm{R}=\text { Hambatan Pada inti besi (ohm) } \\
& \mathrm{t}=\text { waktu (sekon) }
\end{aligned}
$$

Selain menggunakan persamaan (2), perhitungan rugi eddy bisa menggunakan persamaan (3) dan (4).

$\mathrm{P}_{\mathrm{e}}=\mathrm{K}_{\mathrm{e}} \mathrm{B}^{2} \max \mathrm{F}^{2}$

$\mathrm{Ke}=\frac{K \varepsilon v d^{2}}{\rho}$

Keterangan:

$\mathrm{P}_{\mathrm{e}}=$ Rugi-Rugi eddy (Watt)

$\mathrm{K}_{\mathrm{e}}=$ Kostanta eddy (Berdasarkan material)

$\mathrm{B}=$ Fluks Maksimum $\left(\mathrm{Wb} / \mathrm{M}^{2}\right)$

$\mathrm{F}=$ Frekuensi $(\mathrm{Hz})$ 


\section{2) Hysterisis}

Pada hysterisis, semakin gemuk kurva karakteristik hysterisis maka akan semakin besar juga panas yang ditimbulkan. Hal tersebut dipengaruhi oleh besarnya nilai B dan $\mathrm{H}$, serta tidak lepas dari peranan permeabilitas dari bahan. Semakin tinggi nilai permeabilitasnya, maka semakin tinggi pula nilai $B$.

$\mathrm{B}=\mu 0_{\mathrm{H}}$

$\mathrm{H}=\mathrm{N} \mathrm{I}$

Keterangan:

$\mathrm{B}=$ Kerapatan fluksi $\left(\mathrm{Wb} / \mathrm{m}^{2}\right)$

$\boldsymbol{\mu} \boldsymbol{o}=$ Permeabilitas bahan $(\mathrm{Wb} / \mathrm{Am})$

$\mathrm{H}=$ Intensitas medan magnet $(\mathrm{A} / \mathrm{m})$

$\mathrm{N}=$ Jumlah lilitan

$\mathrm{I}=$ Arus (ampere)

Selain itu, nilai frekuensi dan jumlah lilitan sangat berperan untuk proses pemanasan. Semakin tinggi nilai frekuensi dan semakin banyak jumlah lilitan, maka nilai hysterisis akan semakin tinggi.

$P_{h}=K_{h} B^{2} \max F$

Keterangan:

$\mathrm{P}_{\mathrm{h}}=$ Rugi-Rugi Hysterisis (Watt)

$\mathrm{K}_{\mathrm{h}}=$ Kostanta Hysterisis

$\mathrm{B}=$ Fluks Maksimum $\left(\mathrm{Wb} / \mathrm{M}^{2}\right)$

$\mathrm{F}=$ Frekuensi $(\mathrm{Hz})$

\section{HASIL DAN PEMBAHASAN}

Pengujian kinerja tungku induksi dan analisa dilakukan pada dua kondisi. Kondisi pertama adalah pada kondisi tanpa beban, yaitu dengan melihat frekuensi dan bentuk gelombangnya pada keluaran optocoupler. Kondisi kedua yaitu dengan dibebani mosfet dan disambungkan ke cawan.

\section{Pengujian Tanpa Beban}

Gelombang hasil pengukuran pada keluaran rangkaian kontrol dapat dilihat pada Gambar 4.

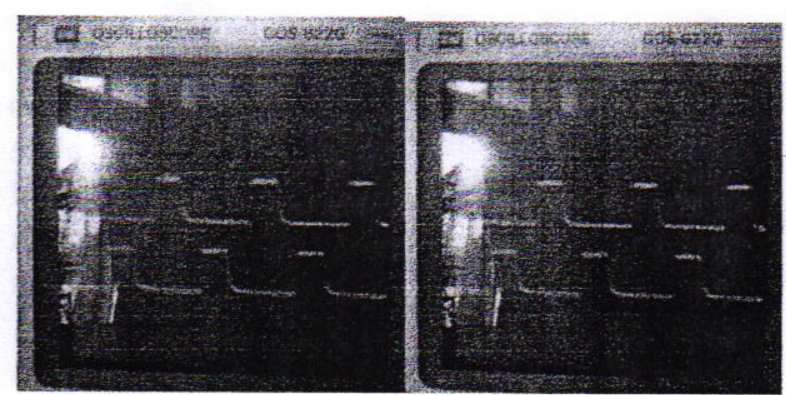

Gambar 4. Gelombang Keluaran Rangkaian Kontrol tanpa beban

(ket: gambar sebelah kiri keluaran opto 1 dan 4, sebelah kanan keluaran opto 2 dan 3)

Pada Gambar 4, terlihat bahwa keluaran rangkaian kontrol pada opto 1, 2, 3, dan 4 memiliki tegangan 11 Volt dengan amplitudo 1 Volt/Div dan 10 time/Div dengan faktor pengali x10 dan frekuensi $325 \mathrm{~Hz}$.

\section{Pengujian Berbeban}

Pada pengujian berbeban, salah satu gelombang keluaran dengan frekuensi $325 \mathrm{~Hz}$ dan amplitudo 5 Volt/Div, 1 Time/Div, dan faktor pengali x10 adalah sebagai berikut.

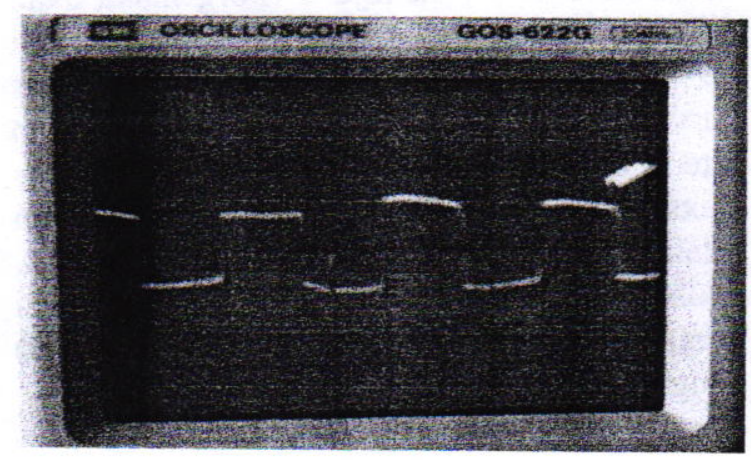

Gambar 5. Gelombang Keluaran Berbeban

1) Pengujian dengan tegangan input ditetapkan

Pada pengujian berbeban tegangan input 50 Volt, dimana gelombang keluaran yang dibebani mosfet berbentuk gelombang clock dan cawan tanpa diisi timah. Hal ini dilakukan dengan tujuan untuk mengetahui pengaruhnya terhadap arus dan waktu pemanasan. Gambar 6 menunjukkan grafik temperatur terhadap waktu pemanasan dengan tegangan ditetapkan 50 Volt. 


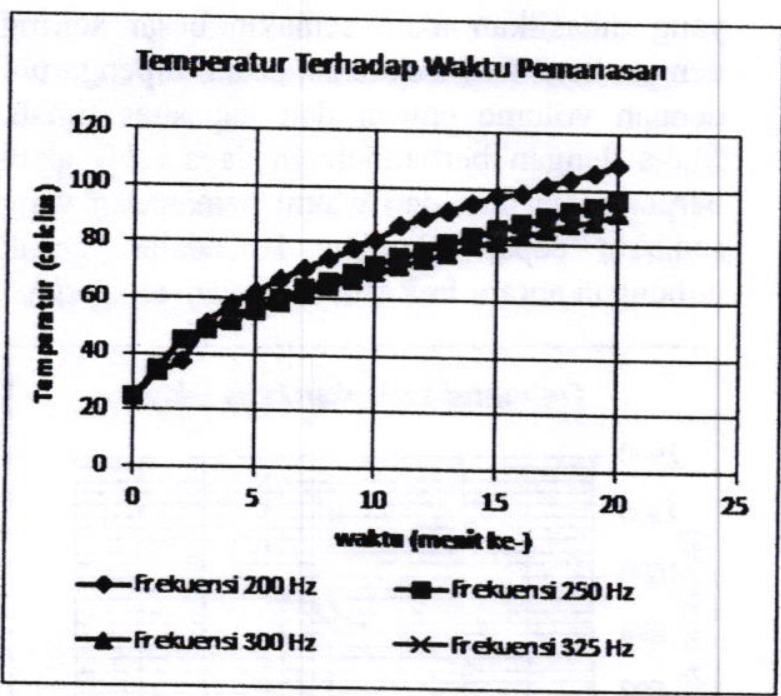

Gambar 6. Temperatur Terhadap Waktu Pemanasan

Dari Gambar 6, terlihat bahwa pada setiap perubahan frekuensi menyebabkan perubahan waktu pemanasan. Waktu pemanasan paling cepat yaitu pada frekuensi $200 \mathrm{~Hz}$, namun pada frekuensi $200 \mathrm{~Hz}$ nilai arus menjadi lebih besar, sehingga daya akan semakin besar dan akan mempercepat waktu pemanasan. Tetapi, dengan besarnya arus akan merusak lilitan karena menyebabkan kumparan menjadi lebih panas. Gambar 7 adalah grafik percobaan yang menunjukan hubungan frekuensi dan arus dengan tegangan 50 Volt.

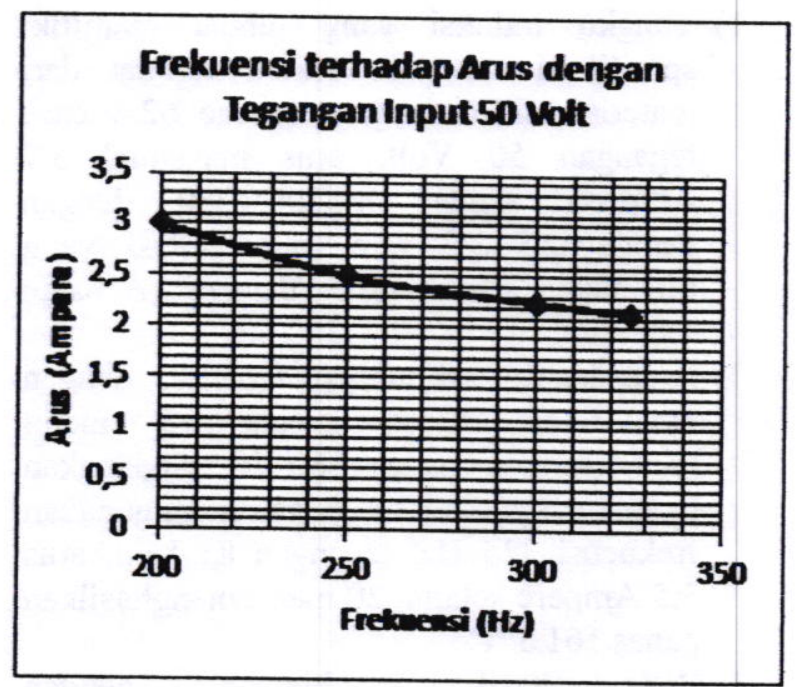

\section{Grafik 7. Frekuensi Terhadap Arus Tegangan Ditetapkan}

Gambar 7 menunjukan bahwa penurunan frekuensi menyebabkan kenaikan arus. Hal tersebut karena dengan penurunan frekuensi akan menyebabkan penurunan impedansi. Penurunan impedansi disebabkan oleh penurunan reaktansi induktif $\left(\mathrm{X}_{\mathrm{L}}\right)$.
2) Pengujian berbeban dengan arus ditetapkan

Pada pengujian ini, arus yang ditetapkan sebesar 3,5 Ampere saat terjadi perubahan frekuensi. Arus ditetapkan 3,5 Ampere karena masih berada di bawah kapasitas maksimum lilitan yaitu 3,7 Ampere. Hal tersebut bertujuan untuk mengetahui pengaruhnya terhadap tegangan input dan waktu pemanasan.

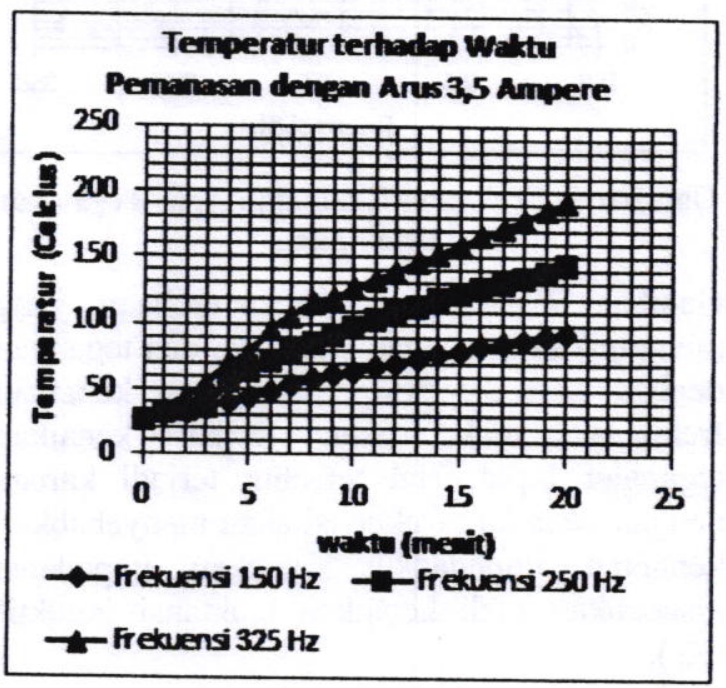

Gambar 8. Temperatur Terhadap Waktu Pemanasan

Dari Gambar 8, terlihat bahwa pada setiap perubahan frekuensi menyebabkan perubahan waktu pemanasan. Waktu pemanasan paling cepat dengan arus 3,5 Ampere yaitu pada frekuensi $325 \mathrm{~Hz}$. Dengan kenaikan frekuensi pada arus ditetapkan 3,5 Ampere maka akan memperbesar tegangan input sehingga daya akan semakin besar dan mempercepat waktu pemanasan. Dengan daya input yang tinggi namun arus kecil, maka pemanasan akan efektif. 


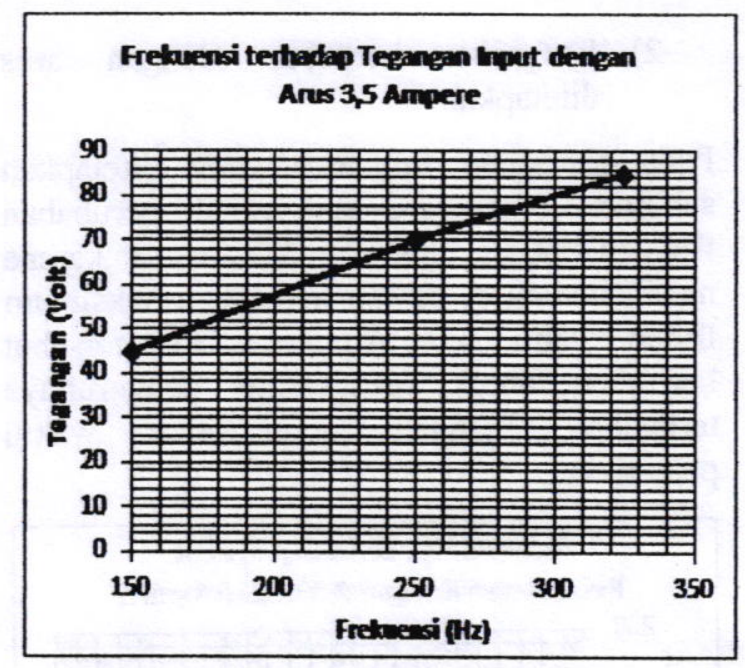

Gambar 9. Frekuensi Terhadap Arus Tegangan Ditetapkan

Gambar 9 adalah grafik percobaan yang menunjukan hubungan frekuensi dan tegangan dengan arus 3,5 Ampere. Dengan kenaikan frekuensi, maka akan terjadi kenaikan tegangan input. Hal tersebut terjadi karena dengan kenaikan frekuensi akan menyebabkan kenaikan impedansi. Kenaikan impedansi disebabkan oleh kenaikan reaktansi induktif $\left(\mathrm{X}_{\mathrm{L}}\right)$.

Dari kedua pengujian tersebut, maka dapat dibandingkan antara hasil pengujian dengan hasil perhitungan. Tabel 1 menunjukkan perbandingan antara hasil pengujian dan hasil perhitungan. Data yang dibandingkan adalah data pada menit ke-15.

\section{Tabel 1. Data Perbandingan Pengujian dan Perhitungan}

\begin{tabular}{|c|c|c|c|c|c|c|c|}
\hline \multicolumn{3}{|c|}{ 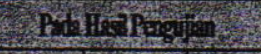 } & \multicolumn{3}{|c|}{ How ing } & \multirow{2}{*}{ 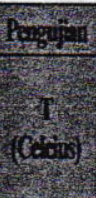 } & \multirow{2}{*}{ 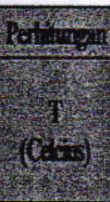 } \\
\hline & $\begin{array}{l}\text { Ans } \\
\text { Aper }\end{array}$ & 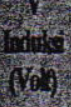 & 19 & (iving & 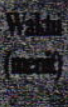 & & \\
\hline 200 & 3,00 & 0,17 & 704203 & 125,06 & 15 & 97,4 & 330,864 \\
\hline 250 & 250 & 0,2 & 880254 & 105,41 & 15 & 85,7 & 516,974 \\
\hline 300 & 2,25 & 0,26 & 1056,310 & 281,39 & 15 & 81,4 & 744,443 \\
\hline 325 & 215 & 0,28 & 1144,330 & 330,25 & 15 & $\pi, 7$ & 873,687 \\
\hline
\end{tabular}

Ket: Tegangan Input 50 Volt

Berdasarkan analisis data yang diambil dari hasil pengujian dengan tegangan input ditetapkan 50 Volt, menunjukkan bahwa frekuensi berpengaruh terhadap arus $e d d y$. Ketika frekuensi dinaikan, maka arus eddy akan meningkat. Hal tersebut, berdampak kepada daya eddy yang dihasilkan. Daya eddy yang dihasilkan akan semakin besar seiring dengan kenaikan frekuensi, selain dipengaruhi dengan volume cawan dan kapasitas timah. Maka dengan bertambahnya daya eddy akan berpengaruh terhadap waktu pemanasan yang semakin cepat. Gambar 10 adalah grafik hubungan antara frekuensi terhadap arus eddy.

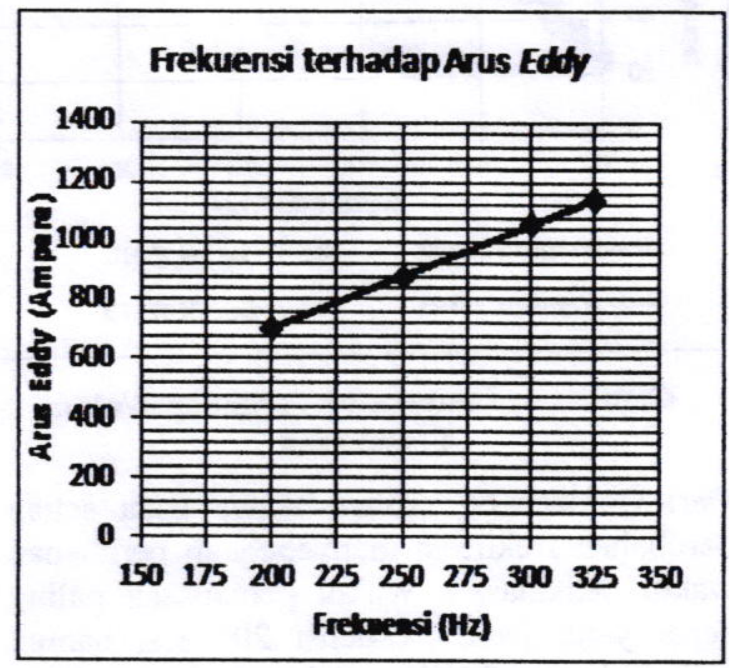

Gambar 10. Frekuensi terhadap Arus Eddy

\section{KESIMPULAN}

Berdasarkan hasil perhitungan dan pengujian yang telah dilakukan, maka dapat ditarik beberapa kesimpulan, diantaranya:

1) Tungku induksi yang dibuat memiliki spesifikasi sebagai berikut: terbuat dari material ST37 dengan volume $62,8 \mathrm{~cm}^{3}$, tegangan 50 Volt, arus maksimal 3,7 Ampere, jumlah lilitan 250 dengan penampang $1,2 \mathrm{~mm}$, dan isolasi yang digunakan adalah asbes dengan ketebalan $1,8 \mathrm{~mm}$.

2) Pada hasil perhitungan teoretik, dengan daya 150 Watt selama 15 menit menghasilkan panas $350{ }^{\circ} \mathrm{C}$. Sedangkan pada hasil pengujian dengan menggunakan frekuensi $325 \mathrm{~Hz}$, tegangan 85 Volt, arus 3,5 Ampere selama 20 menit menghasilkan panas $161,3^{\circ} \mathrm{C}$.

3) Pada hasil perhitungan, dengan menggunakan frekuensi 225,22 $\mathrm{Hz}$ didapatkan temperatur $350{ }^{\circ} \mathrm{C}$ pada waktu pemanasan 15 menit. Sedangkan pada pengujian dengan menggunakan frekuensi $325 \mathrm{~Hz}$ didapatkan temperatur $191,9{ }^{\circ} \mathrm{C}$ untuk cawan kosong dan $161,3{ }^{\circ} \mathrm{C}$ untuk cawan yang terisi timah yang dipanasi selama 20 menit. 


\section{DAFTAR PUSTAKA}

1) Reitz, John R, Frederick J Milford, Robert W Christy. 1993. Dasar Teori Listrik Magnet. Bandung: ITB.

2) Nagrath, IJ. 1985. Enelctric Machines. New Delhi: Tata McGraw-Hill Publishing Company Limited.

3) Holman, J.P. 1995. Perpindahan Kalor Edisi ke Enam. Jakarta: Erlangga.
4) Mawhinney, M.H.. 2000. Industrial Furnace Sixth Edision. North American : Wiley.

5) Wuryanti, Sri. 1995. Perpindahan Panas. Bandung: Penerbit Pusat Pengembangan Pendidikan Politeknik.

6) Irwan, Yusril. 2010. Meterial Teknik. Bandung: Jurusan Teknik Mesin ITENAS.

7) Abrianto, Akuan. 2009. Furnaces. Bandung: Unjani.

8) Handbook Of Energy Conversion for Furnace. 